\title{
Structure and Properties of 1,3,3-Trimethyl-6'-chlorospiro[indoline-2,2'-2H-chromene]
}

\author{
A. D. Pugachev ${ }^{a, *}$, V. V. Tkachev ${ }^{b, c}$, S. M. Aldoshin ${ }^{b}$, N. I. Makarova ${ }^{a}$, I. A. Rostovtseva ${ }^{a}$, \\ A. V. Metelitsa ${ }^{a}$, N. V. Stankevich ${ }^{a}$, G. V. Shilov ${ }^{b}$, and B. S. Lukyanov ${ }^{a}$ \\ ${ }^{a}$ Institute of Physical and Organic Chemistry, Southern Federal University, Rostov-on-Don, 344090 Russia \\ ${ }^{b}$ Institute of Problems of Chemical Physics of the Russian Academy of Sciences, Chernogolovka, 142432 Russia \\ ${ }^{c}$ Institute of Physiologically Active Substances of the Russian Academy of Sciences, Chernogolovka, 142432 Russia \\ *e-mail: artem_d_pugachev@mail.ru
}

Received May 6, 2021; revised June 2, 2021; accepted June 5, 2021

\begin{abstract}
Indoline spiropyran containing an $\sigma$-acceptor chlorine atom in $6^{\prime}$ position of the $2 H$-chromene part of the molecule was synthesized and studied. The use of 1,2,3,3-tetramethyl- $3 \mathrm{H}$-indolium perchlorate as a starting compound made it possible to achieve higher product yields as compared to previous studies. The molecular structure of the compound was established by single crystal X-ray diffraction analysis. The features of the crystal structure and intermolecular interactions were investigated using CrystalExplorer17 software package. The photochromic behavior in acetonitrile solution was studied for the first time. It was found that the merocyanine form of spiropyran is characterized by an absorption maximum at $592 \mathrm{~nm}$, which is $37 \mathrm{~nm}$ closer to the range of the "biological window" in comparison with the nitro-substituted analog.
\end{abstract}

Keywords: spiropyran, photochromism, single crystal X-ray analysis, indoline, $2 H$-chromene

DOI: $10.1134 / \mathrm{S} 1070363221070069$

Spiropyrans represent one of the most interesting classes of organic compounds, the molecules of which can undergo reversible isomerization between the colorless spirocyclic and brightly colored merocyanine forms under the influence of various external factors. This process, in the case of influence of light radiation with various spectral composition on spiropyrans, is called photochromism [1]. Photochromic spiropyrans can be used as easily tunable molecular switches in various advanced industry of science and technology [2-4].

It is known that the introduction of electron-withdrawing substituents into the $2 \mathrm{H}$-chromene moiety of the molecule facilitates the processes of photoinitiated cleavage of the $\mathrm{C}_{\text {spiro }}-\mathrm{O}$ bond [5-7]. Therefore, many studies of the photochromic behavior of spiropyrans have been focused on spiropyrans containing a nitro group in the para-position to the oxygen atom of the $2 \mathrm{H}$-chromene fragment. But, the presence of a nitro group in a spiropyran molecule leads to the involvement of low-lying triple excited states of the molecule in the photophysical mechanism of photoinduced transformations and determines their tendency to photodegradation [8]. Consequently, the search and study of spirocyclic structures modified with electronwithdrawing substituents other than nitro group is a promising area of investigations [9].

This article is devoted to the study of indoline spiropyran 1 containing a chlorine atom as an $\sigma$-acceptor substituent in 6 position. As is known, spiropyrans with halogen substituents can be used as precursors for crosscoupling reactions [10-13].

The target compound was obtained by a modified classical method for the synthesis of spiropyrans proposed by Wizinger [14]. This synthesis method consists in using of 1,2,3,3-tetramethyl-3 $\mathrm{H}$-indolium perchlorate $\mathbf{2}$ instead of 1,3,3-trimethyl-2-methylene indoline (Scheme 1) [15], which made it possible to avoid the formation of a side decondensed product [16 ] and resulted in a higher yield (91.2\% against $34 \%)$. 


\section{Scheme 1.}

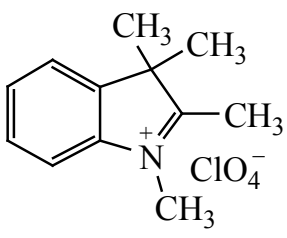

2

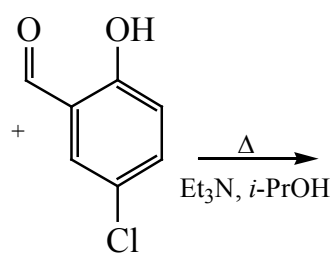

3

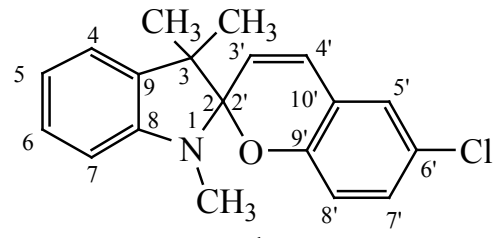

1
The structure of compound $\mathbf{1}$ was confirmed by the data of IR and NMR spectroscopy with two-dimensional methods. In the IR spectrum of compound $\mathbf{1}$, in addition to the absorption bands of $\mathrm{C}=\mathrm{C}\left(1608 \mathrm{~cm}^{-1}\right), \mathrm{C}_{\mathrm{Ar}}-\mathrm{N}$ $\left(1261 \mathrm{~cm}^{-1}\right)$, and $\mathrm{C}_{\text {spiro }}-\mathrm{O}\left(926 \mathrm{~cm}^{-1}\right)$ characteristic of spirocyclic compounds [17], there is an absorption band of the $\mathrm{C}-\mathrm{Cl}$ bond $\left(746 \mathrm{~cm}^{-1}\right)$.

The investigation of the compound 1 structure by ${ }^{1} \mathrm{H}$ NMR showed that, due to the intense magnetic nonequivalent gem-dimethyl groups of the hetarene part, their hydrogen atoms are appeared as two three-proton singlet signals (1.16 and $1.29 \mathrm{ppm})$. The characteristic signals of protons in $3^{\prime}$ and $4^{\prime}$ positions are observed at 5.73 and $6.78 \mathrm{ppm}$ in the form of doublet signals with a spin-spin coupling constant ( $J$-coupling constant) $10.2 \mathrm{~Hz}$, which indicates the cis-configuration of the vinyl fragment $\mathrm{C}^{3^{\prime}}=\mathrm{C}^{4^{\prime}}$. In the ${ }^{1} \mathrm{H}$ NMR spectrum, the three-proton singlet signal of the $\mathrm{NCH}^{3}$ group is present at $2.71 \mathrm{ppm}$. Aromatic proton signals were assigned using the ${ }^{1} \mathrm{H}-{ }^{1} \mathrm{H}$ COSY NMR method. It was established that the multiplet signal at $6.99-7.04 \mathrm{ppm}$ refers to the hydrogen atoms in the $5^{\prime}$ and $8^{\prime}$ positions of the $2 \mathrm{H}$-chromene moiety, and the hydrogen atom in the $7^{\prime}$ position is represented as a doublet signal at $6.63 \mathrm{ppm}$ with a $J$-coupling constant $9.3 \mathrm{~Hz}$.

${ }^{13} \mathrm{C}$ NMR spectrum contains signals of all carbon atoms. Their assignment was carried out using the ${ }^{1} \mathrm{H}-{ }^{13} \mathrm{C}$ HMBC and ${ }^{1} \mathrm{H}-{ }^{13} \mathrm{C}$ HSQC methods. The ${ }^{1} \mathrm{H}-{ }^{13} \mathrm{C}$ HSQC NMR spectrum made it possible to determinate carbon atoms bound with hydrogen atoms. Thus, the signals of carbon atoms at 25.12 and $25.83 \mathrm{ppm}$ correspond to gemmethyl groups, and at $28.87 \mathrm{ppm}$ - to the methyl group at the nitrogen atom. The signals of carbon atoms in $3^{\prime}$ and $4^{\prime}$ positions are located at 120.73 and $128.43 \mathrm{ppm}$, respectively. The aromatic carbon atoms of the indoline fragment are found at 106.83,119.27, 121.48, and $127.64 \mathrm{ppm}$, and at $129.31,126.13,120.04$ and 116.33 ppm for the $2 H$-chromene fragment. Quaternary carbon atoms were assigned with ${ }^{1} \mathrm{H}-{ }^{13} \mathrm{C} \mathrm{HMBC}$.
In ${ }^{15} \mathrm{~N}$ NMR spectrum, a signal of the nitrogen atom is observed at $91.14 \mathrm{ppm}$. A study by the ${ }^{1} \mathrm{H}-{ }^{15} \mathrm{~N}$ HMBC method allows to find a correlation between the signal of the nitrogen atom and the signals of aromatic hydrogen atoms at $3^{\prime}, 4^{\prime}, 4,6$, and 7 positions, as well as with the three-proton signal of the $N$-methyl group at $2.71 \mathrm{ppm}$.

The molecular structure of spiropyran 1 was refined by X-ray diffraction analysis and is shown in Fig. 1. Crystallographic data are given in Table 1 . The independent part of the unit cell contains two molecules, the spirocyclic center of both is realized in the $\mathrm{R}$ position. Representing in Fig. 1, two independent molecules aligned to the left fragment in Fig. 1, while in the right part of the molecule deviate from each other at an angle $23.9^{\circ}$ for one molecule and $25.3^{\circ}$ for the second (the atoms numbers of the second molecule are increased by 20 ) in different directions relative to the line mentally connecting the concurrent (in Fig. 1) atoms $\mathrm{O}^{1^{\prime}}\left(\mathrm{O}^{21 \mathrm{~A}}\right)$ and $\mathrm{C}^{3^{\prime}}\left(\mathrm{C}^{23 \mathrm{~B}}\right)$. Classical intermolecular hydrogen bonds are not formed. In both cases, nitrogen atoms are close to plane, the sum of the angles at the $\mathrm{N}^{1}$ atom is $349.91^{\circ}$, and at the $\mathrm{N}^{21 \mathrm{~A}}$ atom $-351.52^{\circ}$. The values of the lengths of the main bonds, angles and torsion angles are shown in Table 2.

To detect intermolecular interactions in the crystal of compound 1, Hirschfeld surfaces were calculated and obtained. Shape-index is sensitive to very slight changes in surface shape (Fig. 2a). Red continuous areas on the surface, close to triangular and rectangular shape, denote concave areas and represent the atoms involved in the $\pi-\pi$ interaction of molecules above it. Blue continuous areas on the surface, close to triangular and rectangular shape, denote convex areas indicating the atoms involved in the $\pi-\pi$ interaction in this molecule. A large plane area outlined with a blue contour in the surface curvedness image (Fig. 2b) also indicates the $\pi-\pi$ interaction in molecules [18]. In Fig. 2c, the distance (3.554 $\AA$ ) is shown

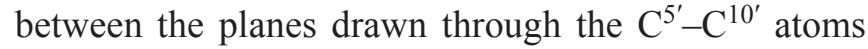
involved in the $\pi-\pi$ interaction, and the angle between the 


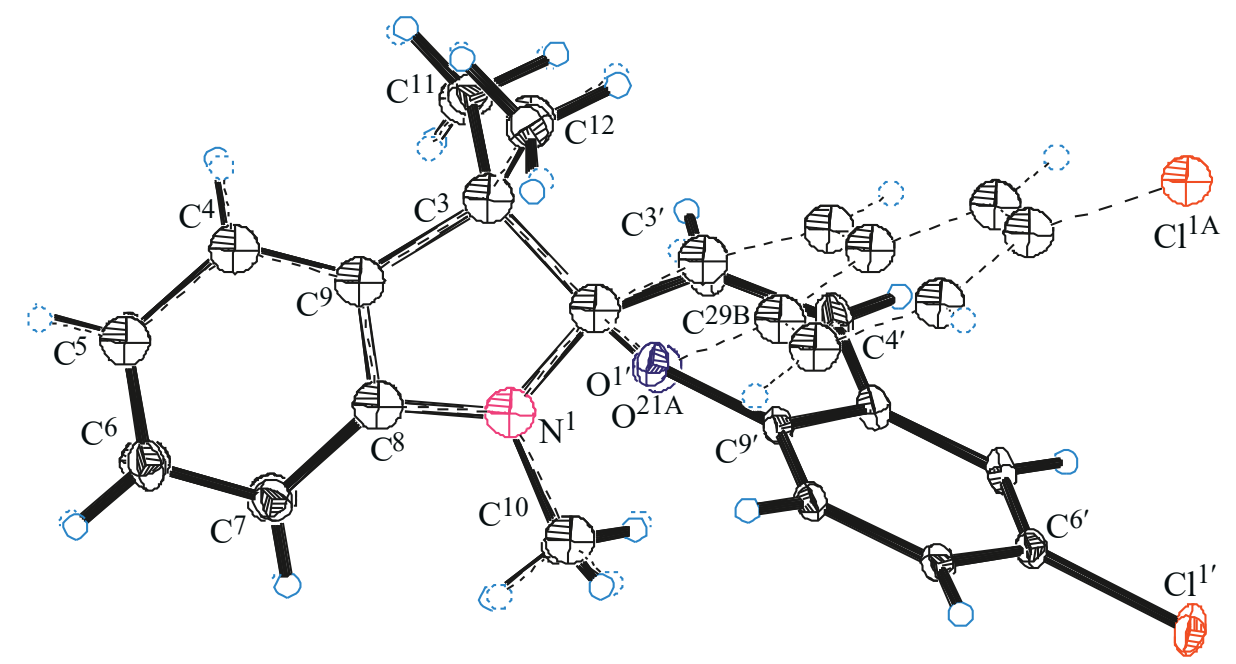

Fig. 1. General view of the molecule of spiropyran 1 in a crystal (CCDC 2079252).

Table 1. Crystallographic data for spiropyran 1

\begin{tabular}{|c|c|}
\hline Parameter & Value \\
\hline Molecular formula & $\mathrm{C}_{19} \mathrm{H}_{18} \mathrm{ClNO}$ \\
\hline Crystal color & Pink \\
\hline$M, \mathrm{~g} / \mathrm{mol}$ & 311.79 \\
\hline$T, \mathrm{~K}$ & 100 \\
\hline Crystal symmetry & Triclinic \\
\hline Space group & $P-1$ \\
\hline$a, \AA$ & $10.7301(7)$ \\
\hline$b, \AA$ & $11.5782(6)$ \\
\hline$c, \AA$ & $13.6543(8)$ \\
\hline$\alpha, \operatorname{deg}$ & $75.269(5)$ \\
\hline$\beta, \operatorname{deg}$ & $90.268(5)$ \\
\hline$\gamma, \operatorname{deg}$ & $76.352(6)$ \\
\hline$V, \AA^{3}$ & $1590.49(17)$ \\
\hline$Z$ & 4 \\
\hline$d, \mathrm{~g} / \mathrm{cm}^{3}$ & 1.302 \\
\hline$F(000)$ & 656 \\
\hline$\mu\left(\mathrm{MoK}_{\alpha}\right), \mathrm{mm}^{-1}$ & 0.241 \\
\hline Crystal size, $\mathrm{mm}$ & $0.30 \times 0.25 \times 0.20$ \\
\hline Diapason $\theta$, degr & $3.00<\theta<31.57$ \\
\hline Measured reflections & 8507 \\
\hline Independent reflections & 3706 \\
\hline Reflections with $F>4 \sigma(F)$ & 6147 \\
\hline Index range & $-13<h<14 ;-15<k<14 ;-18<l<16$ \\
\hline Number of refined parameters & 398 \\
\hline$R$-Factor & $w R_{2} 0.166$ \\
\hline Final value $R$ & 0.0601 \\
\hline
\end{tabular}



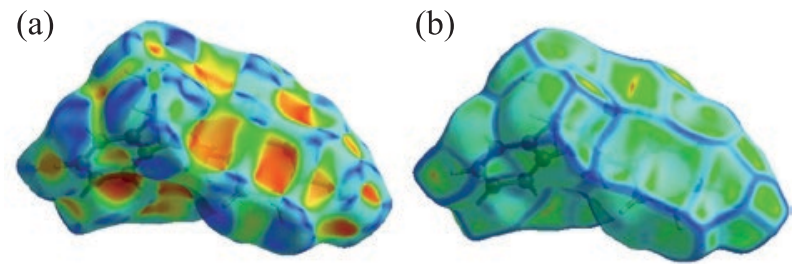

(c)

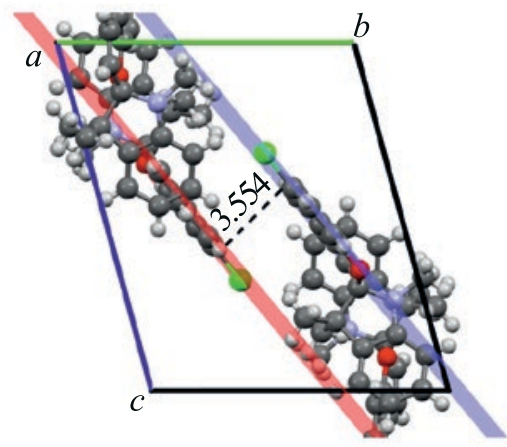

Fig. 2. Hirschfeld surface (a) plotted according to a shapeindex in the range from -1 to 1 a. u., image of the curvedness of the Hirschfeld surface in the range from -4 to 0.4 a. u. (b), and the distance between the planes of the $\mathrm{C}^{5^{\prime}}-\mathrm{C}^{10^{\prime}}$ atoms in the molecules of compound $\mathbf{1}$ in the crystal (c).

planes is $0^{\circ}$, ie, they are parallel. Consequently, paralleldisplaced $\pi-\pi$ stacking is observed in the crystal $[18,19]$.

Donor and acceptor groups in crystal packing can be classified according to the Hirschfeld surface plotted according to the electrostatic potential [19]. On this surface, donors and acceptors of hydrogen bond are represented by blue and red sections on the Hirschfeld surface, respectively (Fig. 3a). From Fig. 3a, it can be seen that the carbon atoms $\mathrm{C}^{6}-\mathrm{C}^{8}$ of the indoline $\pi$-system, oxygen and chlorine atoms, and also carbon of the methyl group at the nitrogen atom can act as acceptors.
The hydrogen bond donors can be $\mathrm{H}^{4}-\mathrm{H}^{7}, \mathrm{H}^{3^{\prime}}, \mathrm{H}^{7^{\prime}}$, and $\mathrm{H}^{8^{\prime}}$ atoms, as well as some hydrogen atoms of the gemmethyl groups. The Hirschfeld surface (Fig. 3b), plotted using the normalized contact distance $d_{\text {norm }}$, shows the atoms of one of the molecules in the crystal involved in intermolecular hydrogen bonds (marked with red dots). For this molecule, it was found that the hydrogen atom of the gem-methyl group $\mathrm{H}^{11 \mathrm{C}}$ is donors of hydrogen bonds, and it forms a bond with the chlorine atom $\mathrm{Cl}^{1}$ of another molecule, as well as the hydrogen atom $\mathrm{H}^{8^{\prime}}$, which implements the bifurcate type of interaction with the carbon atoms $\mathrm{C}^{4}$ and $\mathrm{C}^{9}$ of another molecule. The $\mathrm{C}^{7^{\prime}}$ carbon atom is an acceptor in the nonclassical intermolecular hydrogen bond with $\mathrm{H}^{7^{\prime}}$, as the $\mathrm{C}^{5}$ and $\mathrm{C}^{6}$ carbon atoms, which form nonclassical intermolecular hydrogen bond with the $\mathrm{H}^{3^{\prime}}$ atom.

Investigating other molecules in the crystal, other intermolecular interactions were also found (Fig. 4). It is interesting that the methyl groups at the nitrogen atom interact with each other, forming nonclassical intermolecular hydrogen bonds of the $\mathrm{C}-\mathrm{H} \cdots \mathrm{H}$ type. In addition to these interactions, the molecules in the crystal are kept with 22 shortened contacts. The discovered intermolecular hydrogen bonds and $\pi-\pi$ interactions lead to the fact that molecules in the compound $\mathbf{1}$ crystal are packed into layers (Fig. 5).

The obtained compound $\mathbf{1}$ exists predominantly in the spirocyclic form $\mathbf{A}$ in acetonitrile solution, characterized by three bands with maxima at 205, 222, and $297 \mathrm{~nm}$. UV irradiation effect $\left(\lambda_{\text {irr }} 313 \mathrm{~nm}\right)$ to the spiropyran solution leads to the $\mathrm{C}_{\text {spiro }}-\mathrm{O}$ bond cleavage and the transformation of the molecule into the merocyanine isomer $\mathbf{B}$ (Scheme 2). Due to the photoisomerization under the

Table 2. Main bond lengths, angles, and torsion angles in the spiropyran $\mathbf{1}$ molecule based on X-ray diffraction data

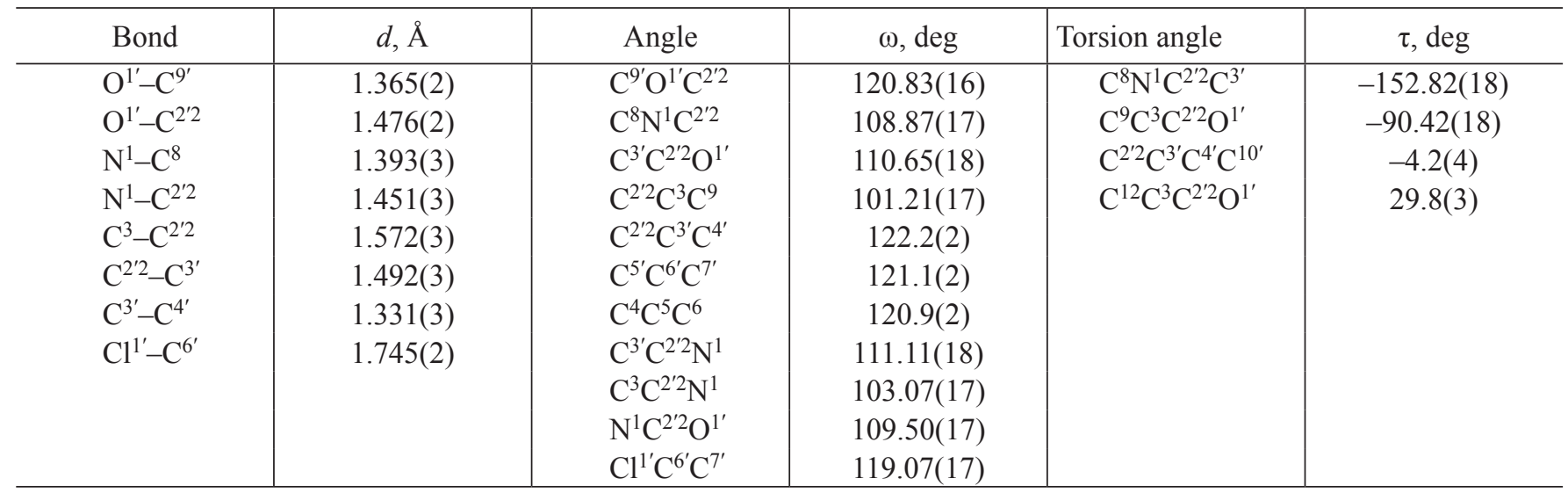


(a)

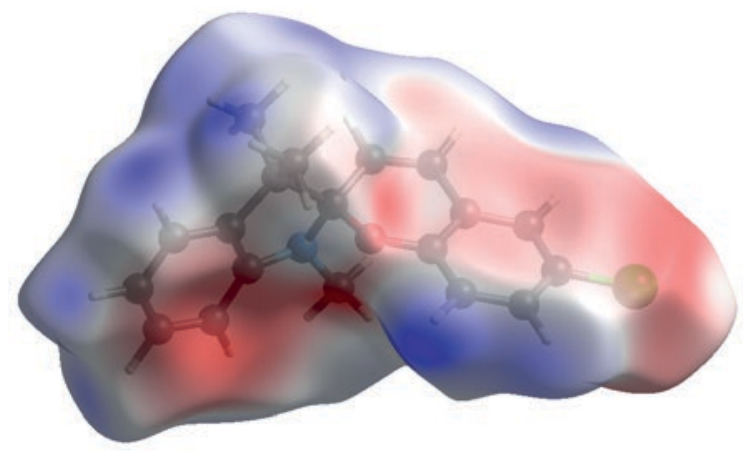

(b)

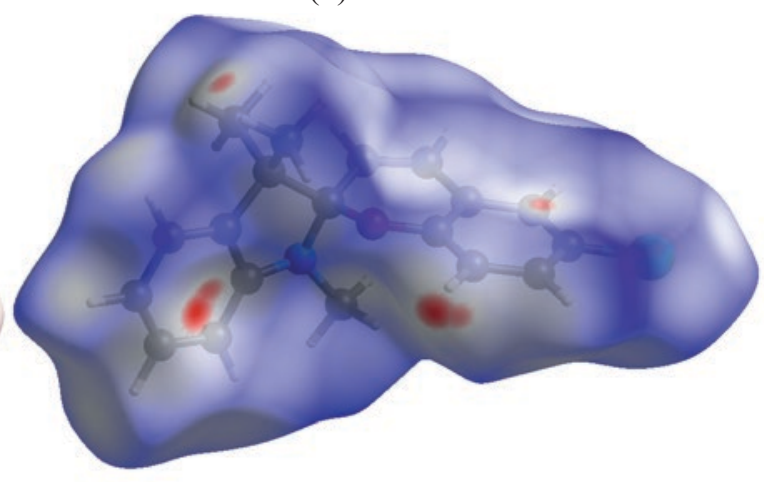

Fig. 3. Hirschfeld surface (a) according to electrostatic potential in the range from -0.0398 to 0.0509 a. u., Hirschfeld surface plotted according to the normalized contact distance $d_{\text {norm }}$, ranging from -0.1235 to 1.3405 a. u. (b).

Scheme 2.<smiles>CN1c2ccccc2C(C)(C)[C@]12CCc1cc(Cl)ccc1O2</smiles>

A<smiles>C[N+]1=C(/C=C/c2cc(Cl)ccc2[O-])C(C)(C)c2ccccc21</smiles>

B influence of UV irradiation, a new absorption band appears in the visible region of the spectrum with a maximum at $592 \mathrm{~nm}$, which is attributed to to the photoinduced isomer B (Fig. 6). After the termination of the irradiation, as a result of the thermal recyclization reaction, the solution was bleached. The isomer $\mathbf{B}$ lifetime $\left(\tau_{\mathbf{B}}\right)$ at room temperature was $19.6 \mathrm{~s}$.

The spectral-kinetic characteristics of isomers $\mathbf{A}$ and $\mathbf{B}$ are given below.

$$
\begin{array}{cl}
\text { Form } & \multicolumn{1}{c}{\lambda, \mathrm{nm}} \\
\text { A } & 205(3.76), 222(3.56), 248 \operatorname{sh}(1.61), 297(0.52), \\
& 330 \operatorname{sh}(0.24) \\
\text { B } & 592
\end{array}
$$

Thus, according to the modified procedure, 1,3,3-trimethyl-6'-chlorospiro[indoline-2,2'-2H-chromene] was obtained with $91.2 \%$ yield. Its structure was investigated using IR, ${ }^{1} \mathrm{H},{ }^{13} \mathrm{C}$, and ${ }^{15} \mathrm{~N}$ NMR spectroscopy (including two-dimensional techniques), as well as elemental analysis. The molecular structure of 1,3,3-trimethyl6'-chlorospiro[indoline-2,2'-2H-chromene] was refined with X-ray diffraction analysis, which revealed the presence of nonclassical intermolecular hydrogen bonds in the structure and shifted $\pi-\pi$-stacking in the $2 \mathrm{H}$-chromene moiety. It was determined that in the crystal of 1,3,3-trimethyl-6'-chlorospiro[indoline-2,2'-

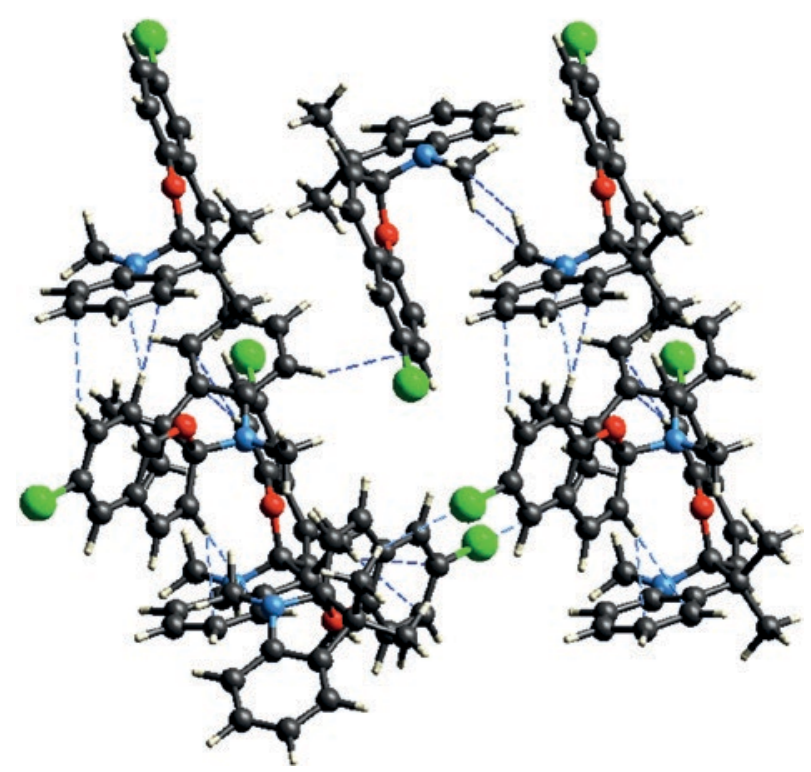

Fig. 4. Intermolecular hydrogen bonds in the crystal of spiropyran 1. 

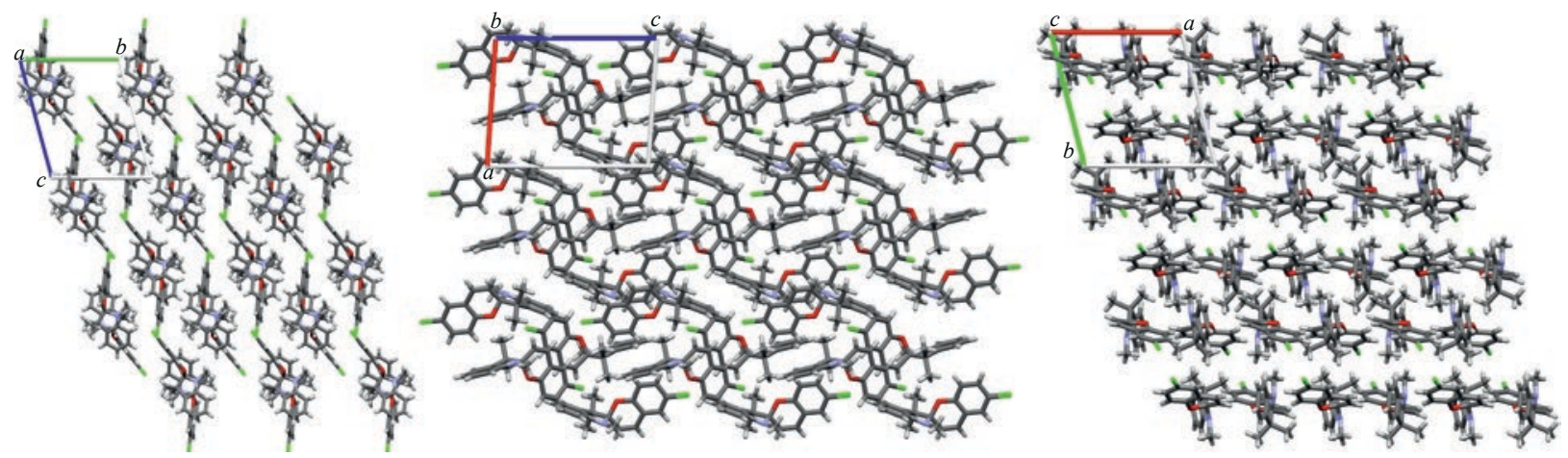

Fig. 5. Molecules arrangement in the crystal of compound $\mathbf{1}$ in projections onto three main planes.

$2 H$-chromene], the molecules are packed into layers. Studies of the photochromic behavior showed that the obtained spiropyran with a chlorine atom at the 6 ' position of the $2 \mathrm{H}$-chromene moiety is characterized by the absorption maximum of the merocyanine isomer at 592 $\mathrm{nm}$, which is $37 \mathrm{~nm}$ closer than the 6'-nitro-substituted compound [20] to the "biological window" range, as well as the functioning for recording and reading information devices.

\section{EXPERIMENTAL}

NMR spectra were recorded on a Bruker AVANCE-600 (600 MHz) spectrometer in $\mathrm{CDCl}_{3}$. IR spectrum was recorded on a Varian Excalibrum 3100 FT-I device with incomplete internal reflection method. Electronic

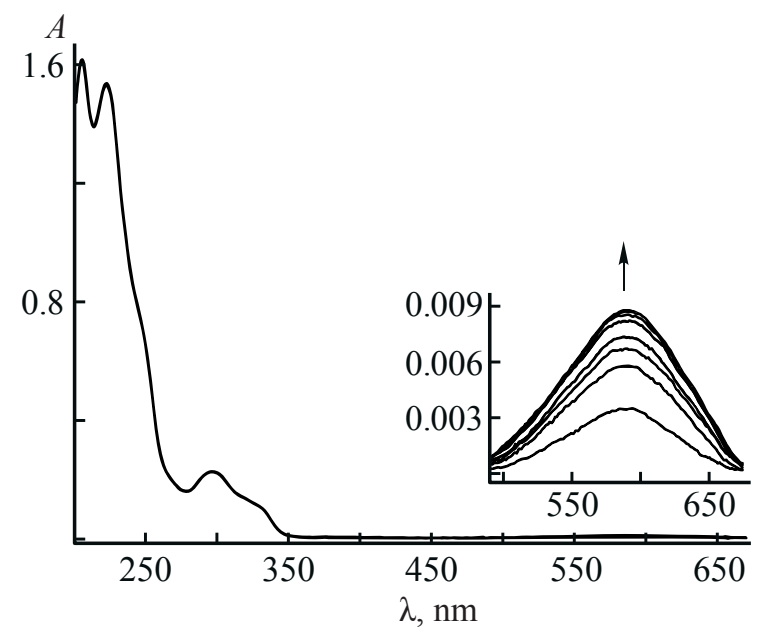

Fig. 6. Changes in absorption spectra of compound 1 under UV irradiation $\left(\lambda_{\text {irr }}=313 \mathrm{~nm}\right)$ in acetonitrile with an interval $5 \mathrm{~s}, c=4.3 \times 10^{-5} \mathrm{M}, 293 \mathrm{~K}$. absorption spectra were recorded on an Agilent 8453 spectrophotometer with a sample thermostating gadget. Photolysis of solutions was performed using a Newport system equipped with a $200 \mathrm{~W}$ mercury lamp with a set of interference filters. Spectral purity acetonitrile (Aldrich) was used to prepare solutions. Elemental analysis was performed by the classical microanalysis method [21]. Melting points were determined using a Fisher-Jones apparatus (ThermoFisher Scientific, United States).

The unit cell parameters of the crystal and the threedimensional set of intensities were obtained on an Xcalibur, Eos autodiffractometer (MoK $K_{\alpha}$-irradiation, graphite monochromator). An empirical account of absorption was carried out using the Multiscan procedure. The structure was solved by a direct method and refined by the full-matrix least squares method (LS) according to $F^{2}$ with the SHELXTL program in the anisotropic approximation for non-hydrogen atoms. In the crystal structure, most $\mathrm{H}$ atoms are localized in the Fourier synthesis of the difference electron density, and then the coordinates and isotropic thermal parameters of all $\mathrm{H}$ atoms were calculated in the LS procedure using the riding model [22]. The crystallographic data has been deposited in the Cambridge Crystallographic Data Center (CCDC 2079252) and can be freely obtained from: www. ccdc.cam.ac.uk/data_request/cif.

Hirschfeld surfaces were calculated by the MP 2 method using the 6-311G(d,p) basis set in the CrystalExplorer v17.5 program [23].

\section{1,3,3-Trimethyl-6' -chlorospiro[indoline2,2' $-2 H$ -} chromene] (1). To a solution of $0.313 \mathrm{~g}(0.002 \mathrm{~mol})$ of 5-chlorosalicylic aldehyde 3 in $20 \mathrm{~mL}$ of propanol-2, $0.547 \mathrm{~g}(0.002 \mathrm{~mol})$ of 1,2,3,3-tetramethyl-3H-indolium perchlorate 2 was added at reflux, then $0.28 \mathrm{~mL}$ ( 1 eq.) of 
triethylamine was added dropwise. The reaction mixture was refluxed with stirring for $25 \mathrm{~min}$, and then cooled, $15 \mathrm{~mL}$ of distilled water was added, and the mixture was extracted with chloroform. The extract was dried with anhydrous $\mathrm{Na}_{2} \mathrm{SO}_{4}$ and the solvent was evaporated. The obtained substance was recrystallized from ethanol. Yield $0.567 \mathrm{~g}(91.2 \%), \mathrm{mp} 90^{\circ} \mathrm{C}$ (ethanol) $\left(\mathrm{mp} 79^{\circ} \mathrm{C}\right.$ [15]). IR spectrum, $v, \mathrm{~cm}^{-1}: 1608(\mathrm{C}=\mathrm{C}), 1261\left(\mathrm{C}_{\mathrm{Ar}}-\mathrm{N}\right)$, $926\left(\mathrm{C}_{\text {spiro }}-\mathrm{O}\right), 746(\mathrm{C}-\mathrm{Cl}) .{ }^{1} \mathrm{H}$ NMR spectrum, $\delta$, ppm $(J, \mathrm{~Hz}): 7.17 \mathrm{t}\left(1 \mathrm{H}, \mathrm{H}^{6}, J 7.6\right), 7.06 \mathrm{~d}\left(1 \mathrm{H}, \mathrm{H}^{4}, J 7.2\right)$, 7.04-6.99 m (2H, $\left.\mathrm{H}^{5^{\prime}}, \mathrm{H}^{8^{\prime}}\right), 6.84 \mathrm{~d}\left(1 \mathrm{H}, \mathrm{H}^{5}, J 7.4\right), 6.78 \mathrm{~d}$ $\left(1 \mathrm{H}, \mathrm{H}^{4^{\prime}}, J 10.2\right), 6.63 \mathrm{~d}\left(1 \mathrm{H}, \mathrm{H}^{7^{\prime}}, J 9.3\right), 6.52 \mathrm{~d}\left(1 \mathrm{H}, \mathrm{H}^{7}\right.$, $J 7.7), 5.73 \mathrm{~d}\left(1 \mathrm{H}, \mathrm{H}^{3^{\prime}}, J 10.2\right), 2.71 \mathrm{~s}\left(3 \mathrm{H}, \mathrm{NCH}_{3}\right), 1.29 \mathrm{~s}$ $\left(3 \mathrm{H}, \mathrm{C}^{3} \mathrm{CH}_{3}\right), 1.16 \mathrm{~s}\left(3 \mathrm{H}, \mathrm{C}^{3} \mathrm{CH}_{3}\right) .{ }^{13} \mathrm{C}$ NMR spectrum, $\delta_{\mathrm{C}}, \mathrm{ppm}: 153.04\left(\mathrm{C}^{9}\right), 148.04\left(\mathrm{C}^{8}\right), 136.55\left(\mathrm{C}^{9}\right), 129.31$ $\left(\mathrm{C}^{8^{\prime}}\right), 128.43\left(\mathrm{C}^{4^{\prime}}\right), 127.64\left(\mathrm{C}^{6}\right), 126.13\left(\mathrm{C}^{5^{\prime}}\right), 124.62$ $\left(C^{10^{\prime}}\right), 121.48\left(C^{4}\right), 120.73\left(C^{3^{\prime}}\right), 120.04\left(C^{6^{\prime}}\right), 119.27$ $\left(C^{5}\right), 116.33\left(C^{7^{\prime}}\right), 106.83\left(C^{7}\right), 104.51\left(C^{2 \prime 2}\right), 51.86\left(C^{3}\right)$, $28.87\left(\mathrm{NCH}_{3}\right), 25.83\left(\mathrm{C}^{3} \mathrm{CH}_{3}\right), 20.12\left(\mathrm{C}^{3} \mathrm{CH}_{3}\right) .{ }^{15} \mathrm{~N} \mathrm{NMR}$ spectrum, $\delta_{\mathrm{N}}$, ppm: $91.14\left(\mathrm{NCH}_{3}\right)$. Found, \%: C 73.42; $\mathrm{H}$ 5.79; $\mathrm{Cl} 11.33 ; \mathrm{N}$ 4.44. $\mathrm{C}_{19} \mathrm{H}_{18} \mathrm{ClNO}$. Calculated, \%: C 73.35; H 5.83; Cl 11.40; N 4.50.

\section{AUTHOR INFORMATION}

A.D. Pugachev, ORCID: http://orcid.org/0000-0002-8624027X

V.V. Tkachev, ORCID: http://orcid.org/0000-0002-13481363

S.M. Aldoshin, ORCID: http://orcid.org/0000-0003-35557442

N.I. Makarova, ORCID: http://orcid.org/0000-0002-71969842

I.A. Rostovtseva, ORCID: http://orcid.org/0000-00029572-3855

A.V. Metelitsa, ORCID: http://orcid.org/0000-0003-36455528

N.V. Stankevich, ORCID: http://orcid.org/0000-00016354-4732

G.V. Shilov, ORCID: http://orcid.org/0000-0001-52797283

B.S. Lukyanov, ORCID: http://orcid.org/0000-0001-99650828

\section{ACKNOWLEDGMENTS}

IR and NMR spectroscopy experimental data, photochemical studies were obtained using the equipment of the Center for
Collective Use of the Southern Federal University "Molecular Spectroscopy."

\section{FUNDING}

The study was financially supported by the Ministry of Science and Higher Education of the Russian Federation within the framework of the state assignment in the field of scientific activity no. 0852-2020-00-19. X-ray diffraction study was performed in accordance with the state assignment, state registration no. AAAA-A19-119092390076-7 (V. V. Tkachev, S. M. Aldoshin).

\section{CONFLICT OF INTEREST}

No conflict of interest was declared by the authors.

\section{OPEN ACCESS}

This article is licensed under a Creative Commons Attribution 4.0 International License, which permits use, sharing, adaptation, distribution and reproduction in any medium or format, as long as you give appropriate credit to the original author(s) and the source, provide a link to the Creative Commons license, and indicate if changes were made. The images or other third party material in this article are included in the article's Creative Commons license, unless indicated otherwise in a credit line to the material. If material is not included in the article's Creative Commons license and your intended use is not permitted by statutory regulation or exceeds the permitted use, you will need to obtain permission directly from the copyright holder. To view a copy of this license, visit http://creativecommons.org/licenses/by/4.0/.

\section{REFERENCES}

1. Bouas-Laurent, H. and Dürr, H., Pure Appl. Chem., 2001, vol. 73, no. 4, p. 639. https://doi.org/10.1351/pac200173040639

2. Klajn, R., Chem. Soc. Rev., 2014, vol. 43, p. 148. https://doi.org/10.1039/c3cs60181a

3. Feringa, B.L., Angew. Chem. Int. Ed., 2017, vol. 56, p. 11060 . https://doi.org/10.1002/anie.201702979

4. Pugachev, A.D., Mukhanov, E.L., Ozhogin, I.V., Kozlenko, A.S., Metelitsa, A.V., and Lukyanov, B.S., Chem. Heterocycl. Compd., 2021, vol. 57, no. 2, p. 122. https://doi.org/10.1007/s10593-021-02881-y

5. Bertelson, R.C., in Organic Photochromic and Thermochromic Compounds. Topics in Applied Chemistry, Crano, J.C. and Guglielmetti, R.J., Eds., Boston: Springer, 2002, p. 11. https://doi.org/10.1007/0-306-46911-1_2

6. Aldoshin, S., in Organic Photochromic and Thermo-

RUSSIAN JOURNAL OF GENERAL CHEMISTRY Vol. 91 No. 72021 
chromic Compounds. Topics in Applied Chemistry, Crano, J.C. and Guglielmetti, R.J., Eds., Boston: Springer, 2002, p. 297. https://doi.org/10.1007/0-306-46912-X_8

7. Dorogan, I.V. and Minkin, V.I., Chem. Heterocycl. Compd., 2016, vol. 52, no. 9, p. 730. https://doi.org/10.1007/s10593-016-1956-X

8. Chibisov, A.K. and Görner, H., J. Phys. Chem. (A), 1997, vol. 101, p. 4305. https://doi.org/10.1021/jp9625691

9. Pugachev, A.D., Ozhogin, I.V., Lukyanova, M.B., Lukyanov, B.S., Kozlenko, A.S., Rostovtseva, I.A., Makarova, N.I., Tkachev, V.V.,Aldoshin, S.M., and Metelitsa,A.V., J. Mol. Struct., 2021, vol. 1229, p. 129615. https://doi.org/10.1016/j.molstruc.2020.129615

10. Schmidt, S.B., Kempe, F., Brügner, O., Walter, M., and Sommer, M., Polym. Chem., 2017, vol. 8, no. 35, p. 5407. https://doi.org/10.1039/C7PY00987A

11. Qu, L., Xu, X., Song, J., Wu, D., Wang, L., Zhou, W., Zhou, X., and Xiang, H., Dyes Pigm., 2020, vol. 181, p. 108597. https://doi.org/10.1016/j.dyepig.2020.108597

12. Ma, Z., Meng, X., Ji, Y., Li, A., Qi, G., Xu, W., Zou, B., Ma, Y., Kuang, G.-C., and Jia, X., Dyes Pigm., 2019, vol. 162, p. 136. https://doi.org/10.1016/j.dyepig.2017.11.036

13. Meng, X., Chen, C., Qi, G., Li, X., Wang, K., Zou, B., and Ma, Y., ChemNanoMat., 2017, vol. 3, no. 8, p. 569. https://doi.org/10.1002/cnma.201700120

14. Wizinger, B. and Wennig, H., Helv. Chim. Acta, 1940, vol. 23, no. 1, p. 247.

https://doi.org/10.1002/hlca.19400230133
15. Silvia, T.R., Ana, V.S.L., and González, E.A.S., Synth. Commun., 1995, vol. 25, no. 1, p. 105. https://doi.org/10.1080/00397919508010795

16. Keum, S.R., Ku, B.S., Shin, J.T., Ko, J.J., and Buncel, E., Tetrahedron, 2005, vol. 61, no. 28, p. 6720. https://doi.org/10.1016/j.tet.2005.05.005

17. Dzhaparidze, K.G., Spirokhromeny (Spirochromena), Tbilisi: Metsniereba, 1979.

18. Luo, Y.H., Yang, L.J., Han, G., Liu, Q.L., Wang, W., Ling, Y., and Sun, B.W., J. Mol. Struct., 2014, vol. 1076, p. 679. https://doi.org/10.1016/j.molstruc.2014.07.069

19. Kargar, H., Behjatmanesh-Ardakani, R., FallahMehrjardi, M., Torabi, V., Munawar, K.S., Ashfaq, M., and Tahir, M.N., J. Mol. Struct., 2021, vol. 1233, p. 130105. https://doi.org/10.1016/j.molstruc.2021.130105

20. Shirinian, V.Z., Barachevsky, V.A., Shimkin, A.A., Krayushkin, M.M., Mailian, A.K., Tsyganov, D.V., Vinter, O.A., and Venidiktova, O.V., Russ. Chem. Bull., 2010, vol. 59, no. 4, p. 828. https://doi.org/10.1007/s11172-010-0168-2

21. Gel'man, N.E., Terent'eva, E.A., Shanina, T.M., and Kiparenko, L.M., Metody kolichestvennogo organicheskogo elementnogo analiza (Methods for Quantitative Organic Elemental Analysis), Moscow: Khimiya, 1987.

22. Sheldrick, G.M., SHELXTL v. 6.14, Structure Determination Software Suite, Bruker AXS, Madison, Wisconsin (USA), 2000.

23. Turner, M.J., McKinnon, J.J., Wolff, S.K., Grimwood, D.J., Spackman, P.R., Jayatilaka, D., and Spackman, M.A., Crystal Explorer 17, University of Western (Australia), 2017. 